\title{
Exchange Market Pressure and Monetary Policy: Asia and Latin America in the 1990s
}

\section{EVAN TANNER*}

Exchange market pressure (EMP), the sum of exchange rate depreciation and reserve outflows (scaled by base money), summarizes the flow excess supply of money in a managed exchange rate regime. This paper examines Brazil, Chile, Mexico, Indonesia, Korea, and Thailand, and finds that monetary policy affects EMP as generally expected: contractionary monetary policy helps to reduce EMP. The monetary policy stance is best measured by domestic credit growth (since interest rates contain both policy-and market-determined elements). In response to higher EMP, monetary authorities boosted domestic credit growth both in Mexico (confirming previous research) and in the Asian countries. [JEL E4, F3, F4]

he term "exchange market pressure" (EMP) generally refers to movements in two key external sector variables: (official) international reserve holdings and the (nominal) exchange rate. ${ }^{1}$ Girton and Roper's (1977) seminal paper more precisely defined EMP as the sum of exchange rate depreciation and reserve

\footnotetext{
*Evan Tanner was an Economist in the IMF Western Hemisphere Department when this paper was written. The author gratefully acknowledges the many helpful and interesting comments from Jose Bailen, Benedikt Braumann, Paul Burkett, Robert Flood, Jeff Franks, Cheng-Hoon Lim, Jorge Antonio Chan Lau, Juan Carlos Jaramillo, Martin Kaufman, Franscisco Nadal de Simone, Thomas Reichmann, Claudia Paz Sepulveda, Bob Traa, and Philip Young. The author is also grateful for conversations with Andy Berg, Kevin Carey, Carl Walsh, and Larry Christiano about general issues of model specification, and for assistance from Gloria Bustillo, Patricia Quiros, and Jorge Shepherd.

${ }^{1}$ Of course, strains on a country's external sector might also be measured by the differential between domestic and world interest rates. In this vein, Eichengreen, Rose, and Wyplosz (1996) construct an EMP measure that includes the interest differential. Here, the interest differential will be treated as a determinant of EMP.
} 
outflows (scaled by base money). ${ }^{2}$ Such a measure summarizes the difference between the growth rates of money supply and demand under managed exchange rate regimes. ${ }^{3}$

Recent difficulties in Asia and Latin America highlight several issues regarding EMP. For example, the relative importance of foreign and domestic factors on EMP in these countries is widely debated. To be sure, most observers believe that certain fundamental domestic factors - such as monetary, fiscal, and financial policies-affect a country's external sector. However, shocks from abroad do so as well, in both asset and goods markets. In this vein, many observers have stressed the importance of contagious elements in global markets, especially during the $1990 \mathrm{~s}^{4}$

This paper addresses three related questions regarding the relationship between EMP and monetary policy in selected Asian and Latin American countries. First, does monetary policy affect EMP in the way that standard monetary frameworks predict? For example, does contractionary monetary policy help reduce EMP? Second, how should the stance of monetary policy be measured? Currently, most authors emphasize interest rates, ${ }^{5}$ whereas older literature emphasized monetary aggregates. For example, in the traditional monetary approach to the balance of payments, the domestic credit component of the monetary base was considered to be the variable controlled by policy makers. This paper proposes a compromise that emphasizes domestic credit growth as the policy variable but also includes the differential between domestic and U.S. interest rates. ${ }^{6}$ Third, in what sense is the stance of monetary policy itself a function of EMP? Do monetary authorities respond to increases in EMP by tightening monetary policy? Or, do they sterilize EMP increases with more domestic credit, as several recent papers (Flood, Garber, and Kramer, 1996; Calvo and Mendoza, 1996) suggest?

To address these questions, this paper develops a vector autoregression (VAR) framework, whose variables include EMP, domestic credit growth, and the differential between domestic and foreign interest rates. ${ }^{7}$ This framework shows the

\footnotetext{
${ }^{2}$ Other papers that present models of EMP include Connolly and Da Silveira (1979) for Brazil; Brisimis and Leventakis (1984) for Greece; Weymark (1995) for Canada; Wohar and Lee (1992) for Korea; and Burkett and Richards (1993) for Paraguay. Ahluwalia (2000) constructs a variant of EMP for several countries. More recently, several papers have used EMP indirectly to construct a discrete crisis indicator. These include Eichengreen, Rose, and Wyplosz (1996) and Kaminsky, Lizondo, and Reinhart (1998). However, different from other papers, this one examines the recent behavior of EMP in emerging markets, and it does so directly.

${ }^{3}$ Under managed or dirty floats, authorities limit exchange rate flexibility by purchasing or selling international reserves. Under such a regime, it would be misleading to focus on either exchange rate growth or reserves movements alone.

${ }^{4}$ For a test of contagious effects on interest rates in Mexico, Chile, and Argentina, see Edwards (1998).

${ }^{5}$ See, for example, Bernanke and Blinder (1992), who use the federal funds rate to measure the stance of monetary policy in the United States.

${ }^{6}$ Basurto and Ghosh (2000) also argue that, for the Asian economies, interest rates may not be good indicators of the stance of monetary policy.

${ }^{7}$ In a monetary framework, a scale variable for money demand should also be included. Most frequently, this variable is gross domestic product (GDP). However, this study uses monthly data, for which GDP is not available. A proxy, the industrial production index, is available for some countries. Difficulties in using this variable are discussed in the paper.
} 
response of EMP to innovations in the other two variables (including shocks to monetary policy). ${ }^{8}$ And, the framework yields a policy reaction function that summarizes the effects of lagged innovations in both EMP and the interest differential on domestic credit growth.

The countries in this study are Brazil, Chile, Mexico, Indonesia, Korea, and Thailand. In choosing countries, it is natural to compare the Mexican experience of 1994-95 with the more recent episodes in major Asian economies like Indonesia, Korea, and Thailand. And Brazil, Mexico, and Chile help illustrate different responses to both the Asian crisis of 1997-98 and the Russian default in 1998. ${ }^{9}$

Issues raised in this paper are closely linked to several recent debates. For example, during the Asian difficulties, many asked whether policy makers could successfully defend exchange rates with tight monetary policy, and, specifically, with high interest rates. ${ }^{10}$ Some have even suggested that a Laffer curve exists under certain conditions: contractionary policy may cause panic among investors and thus a loss (rather than a gain) of a currency's value. ${ }^{11}$ This paper helps to test such a proposition. ${ }^{12}$ Unlike other papers, though, this one focuses on EMP rather than exchange rates. Since the Asian countries in this study did not pursue either fixed or freely floating exchange rate policies, it may be misleading to examine exchange rate behavior without considering reserves as well. For example, Korea gained international reserves during 1998, and EMP was negative, even as the won depreciated. Since the EMP measure includes both exchange depreciation and reserves, it provides a more complete picture than either variable alone. Critically, this paper finds that monetary policy affects EMP as expected: contractionary monetary policy helps to reduce EMP. ${ }^{13}$

A related issue is whether monetary policy was "tight" or "loose" in emerging market economies during and after the more recent crises. Regarding the Mexican crisis of 1994-95, there is much agreement that reserve outflows were initially sterilized with increases of domestic credit by the central bank (see, for example, Calvo and Mendoza, 1996; Flood, Garber, and Kramer, 1996). Regarding Asia, there is considerable debate as to whether monetary policy was "tight" or "loose." The popular press highlighted episodes of tight monetary policy. However, according to an IMF study (Lane and others, 1999) the postcrisis monetary targets

\footnotetext{
${ }^{8}$ In a VAR, such innovations are contemporaneously uncorrelated with the error term of any other variable and hence may be thought of as "exogenous" or "policy" variables. Others have applied such techniques to US monetary policy, including Christiano (1995); Christiano, Evans, and Eichenbaum (1998); and Bernanke and Mihov (1998). For an application to Mexico, see Edwards and Savastano (1998).

${ }^{9}$ All data are monthly, covering the period 1990:1 through late 1998.

${ }^{10}$ See Radelet and Sachs (1998), Furman and Stiglitz (1998), Goldfajn and Baig (1998), Goldfajn and Gupta (1998), Ghosh and Ghosh (1999), and Lane and others (1999). Another, broader question that arose during the recent crises was whether the benefits of contractionary monetary policy outweighed their costs. This paper does not address that question.

${ }^{11}$ See, for example, Corsetti, Pesenti, and Roubini (1998).

${ }^{12}$ This issue is addressed by Corsetti, Pesenti, and Roubini (1998); Krugman (1998); and is tested by Goldfajn and Gupta (1998).

${ }^{13}$ While the stance of monetary policy is better measured in this context by domestic credit growth, rather than interest rates (which contain both policy- and market-determined elements), both measures affect EMP as expected, and significantly so.
} 


\section{Evan Tanner}

in Korea and Thailand, which both countries met, were contractionary, but not drastically so. (By contrast, money growth in Indonesia exceeded its targets.) Elsewhere, Goldfajn and Baig (1998) find no evidence that postcrisis monetary policy in Asia was "overly tight." At another extreme, Corsetti, Pesenti, and Roubini (1998) characterize monetary policy in these countries as "loose," at least in the early stages of the crisis.

The current framework addresses this question somewhat differently: it asks whether monetary policy was systematically tightened or loosened in response to higher EMP. Critically, this paper finds that, in response to higher EMP, monetary authorities in the Asian countries increased domestic credit growth, much as the Mexicans did during the 1994-95 crisis. Such a finding should not be surprising: in the initial phases of the crisis (i.e., early 1997) Asian central banks extended credit to ailing financial institutions but did not raise interest rates. And, while this policy reaction was clearly destabilizing, it may have been politically difficult to avoid.

The remainder of the paper is organized as follows. In Part I, EMP is motivated in a monetary framework. In Part II, a vector autoregression approach is presented. In Part III, empirical estimates are presented. In Part IV, some conclusions are presented.

\section{Motivation for Exchange Market Pressure}

Many countries permit some exchange rate flexibility but also intervene in markets with purchases or sales of international reserves. For such regimes, it is misleading to focus on either exchange rate growth or reserves movements alone. Instead, under such a managed float, EMP represents the difference between the growth rates of domestic money supply and money demand, reflected in both exchange rate and reserve movements. To see this, consider the following simple monetary model. On the demand side, the growth of real base money $\left(m_{t}\right)$ is:

$$
m_{t}=\Delta M_{t} / M_{t-1}-\pi_{t}
$$

where $M_{t}$ is nominal (base) money at time $t$ and $\pi_{t}$ is the inflation rate $\left(\Delta P_{t} / P_{t-1}\right.$, where $P_{t}$ is the price level at time $\left.t\right) .{ }^{14}$ The inflation rate is linked to world inflation $\pi_{t}^{*}$ through the rate of growth of the nominal exchange rate $e_{t}$ (units of the country's currency per U.S. dollar):

$$
e_{t}=\pi_{t}-\pi_{t}^{*}+z_{t}
$$

where $z_{t}$ is the deviation from purchasing power parity. On the supply side, the two components of nominal base money are international reserves $R_{t}$ and net domestic assets $D_{t}$. Thus,

$$
\Delta M_{t} / M_{t-1}=\left(\Delta R_{t}+\Delta D_{t}\right) / M_{t-1}=r_{t}+\delta_{t}
$$

${ }^{14}$ Of course, while not explicitly modeled here, the growth rate of money demand $m_{t}$ is determined by the growth of transactions (i.e., gross domestic product) and opportunity costs (i.e., interest rates). 
where $r_{t}=\Delta R_{t} / M_{t-1}$ and $\delta_{t}=\Delta D_{t} / M_{t-1}$. The above equations restate the traditional monetary approach. Assuming that purchasing power parity holds and world inflation equals zero $\left(z_{t}=\pi_{t}^{*}=0\right)$, substitute equations (2) and (3) into (1) and rearrange to obtain an expression for $E M P$ :

$$
E M P_{t} \equiv e_{t}-r_{t}=\delta_{t}-m_{t}
$$

According to equation (4), exchange rate depreciation plus reserve outflows (scaled by base money) equals the difference between the growth rates of the domestic component of the monetary base $\left(\delta_{t}\right)$ and money demand $\left(m_{t}\right) .{ }^{15}$ Under a fixed exchange rate regime, $e_{t}=0$; with freely floating exchange rates, $r_{t}=0$.

Equation (4) shows the link between EMP and monetary policy, measured by $\delta_{t}$, the portion of the monetary base controlled by domestic policy makers. If real money demand is constant $(m=0), E M P$ and $\delta$ should move together, one-to-one. Of course, to control $\delta$, central banks may set interest rates. In this sense, contractionary monetary policy will raise the differential between domestic and world (U.S.) interest rates $(\phi)$, encourage capital inflows, and thus reduce EMP. However, $\phi$ may be a noisy indicator of monetary policy, since it contains market elements as well, including expected exchange depreciation and a risk premium.

Plots of EMP, $\delta$, and $\phi$ for Brazil, Chile, Mexico, Indonesia, Korea, and Thailand (Figure 1) illustrate several points. ${ }^{16}$ First, these plots confirm the link between $E M P$ and monetary policy: EMP and $\delta$ move together closely, especially during certain crisis periods. The relationship between EMP and $\phi$ is not as close, further suggesting that $\phi$ is a noisy indicator of monetary policy. These observations are confirmed in an earlier version of this paper. ${ }^{17}$ As further evidence of the comovements of these variables, note that in Mexico both EMP and $\delta$ increased dramatically (while $\phi$ fell) during the severe 1994-95 crisis and during two previous, less severe episodes (November 1993 and March/April 1994). By mid-1995, in the aftermath of the crisis, both EMP and $\delta$ fell, while $\phi$ increased dramatically and did not return to its precrisis level until mid-1997. By contrast, the Central Bank of

${ }^{15}$ This definition may also be obtained for the more general case of non-zero $\pi^{*}$. An even more general definition of EMP is $(e-\alpha r)$ where $\alpha$ is a reduced-form coefficient that depends on several underlying structural parameters. Under standard assumptions of the monetary approach to exchange rates and the balance of payments, $\alpha$ should be unity. Subsequently, other authors relaxed these assumptions (see, for example, Weymark, 1998) and found that $\alpha$ might be difficult to obtain. Nonetheless, $\alpha$ is commonly set to unity, as doing so yields an informative indicator (although not necessarily implied by a deeper structural model). Alternative scalings, not directly related to the monetary approach, are proposed by Eichengreen, Rose, and Wyplosz (1996) and Ahluwalia (2000).

${ }^{16}$ All data in this study are monthly, obtained from the IMF's International Financial Statistics. For all countries, international reserves and the monetary base are defined as Series 11.d and 14, respectively. For Brazil, Indonesia, and Thailand, domestic credit is defined as the sum of central bank credit to the government (Series 12a) and to the financial system (for Indonesia, 12e; for Thailand and Brazil,12e and 12f). For Chile, Mexico, and Korea, domestic credit is defined as the difference between the monetary base and net foreign assets (Series 14 minus series 12 plus 16c plus 16cl.) In all cases, $\phi$ is measured as the difference on deposit interest rates.

${ }^{17}$ Tanner (1999), wherein simple bivariate regressions of EMP on $\delta$ and $\phi$ are presented. Adjusted $\mathrm{R}^{2}$ statistics from these regressions indicate the importance of money supply shocks in explaining total EMP. These statistics were: Brazil, 0.57; Chile, 0.12; Mexico, 0.49; Indonesia, 0.01; Korea, 0.34; and Thailand, 


\section{Evan Tanner}

Figure 1. EMP, Domestic Credit Growth $(\delta)$, and Interest Differential $(\phi)$ : Selected Countries

Brazil (Post-Real plan)

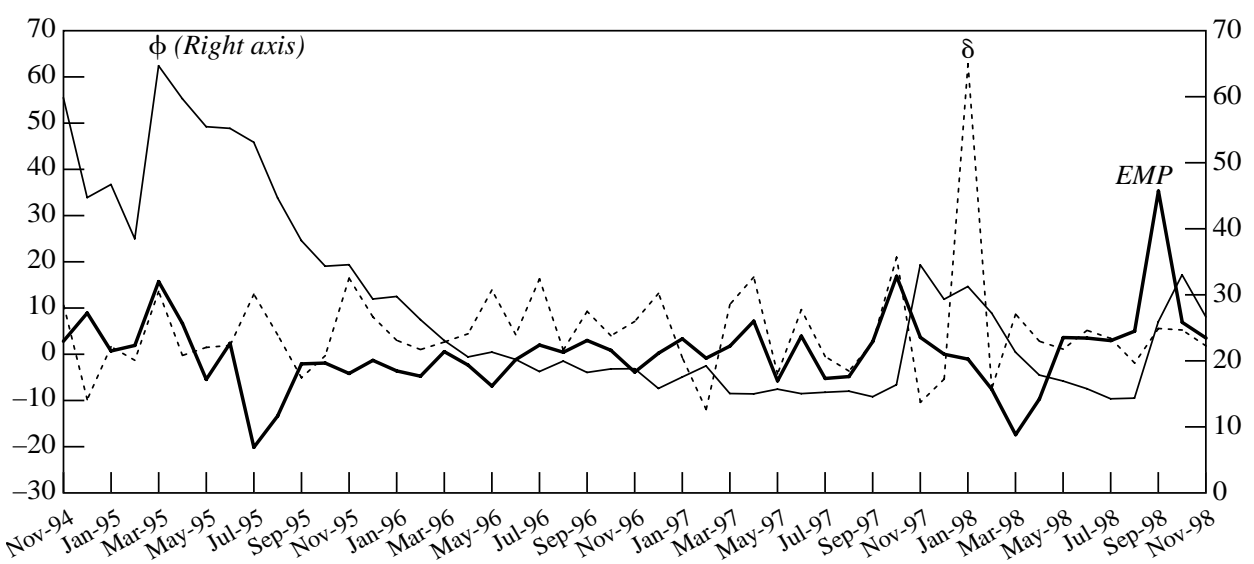

Chile

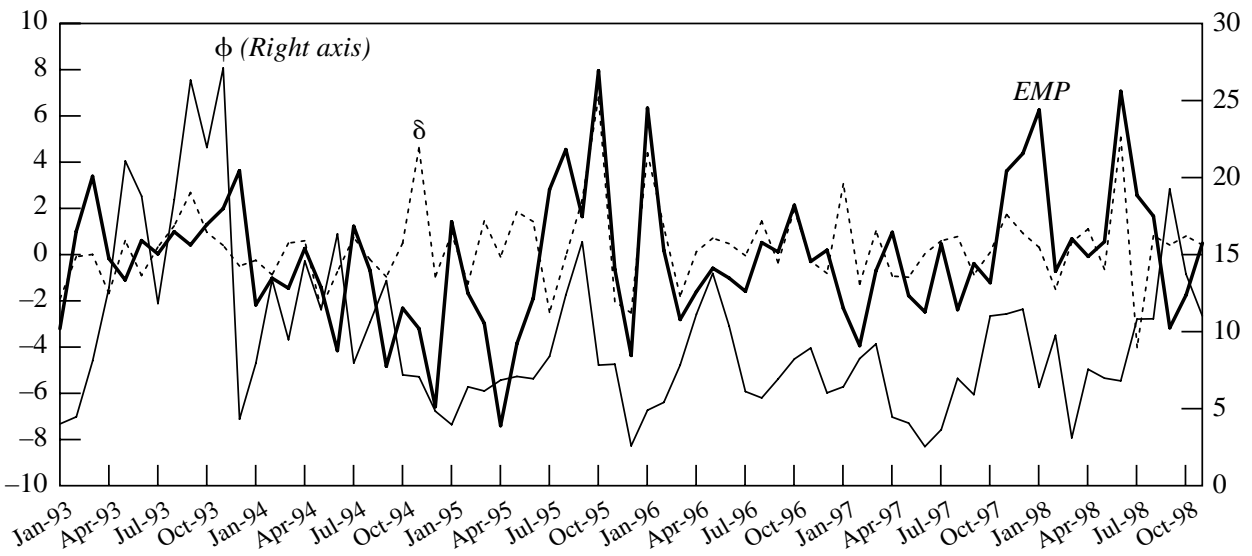

Mexico

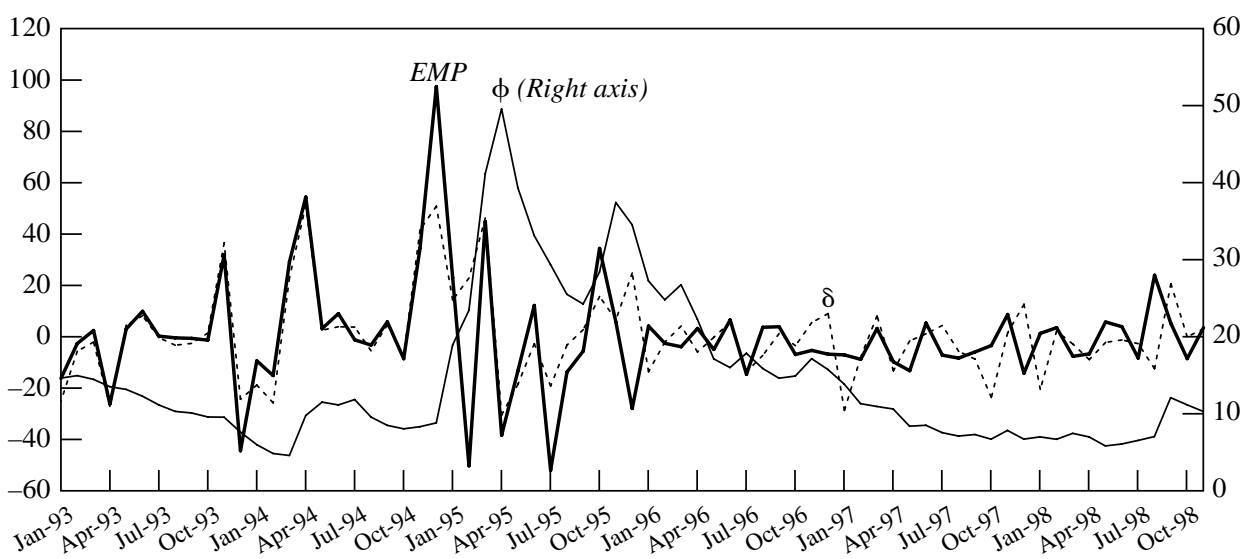


Figure 1. (Continued)

Indonesia

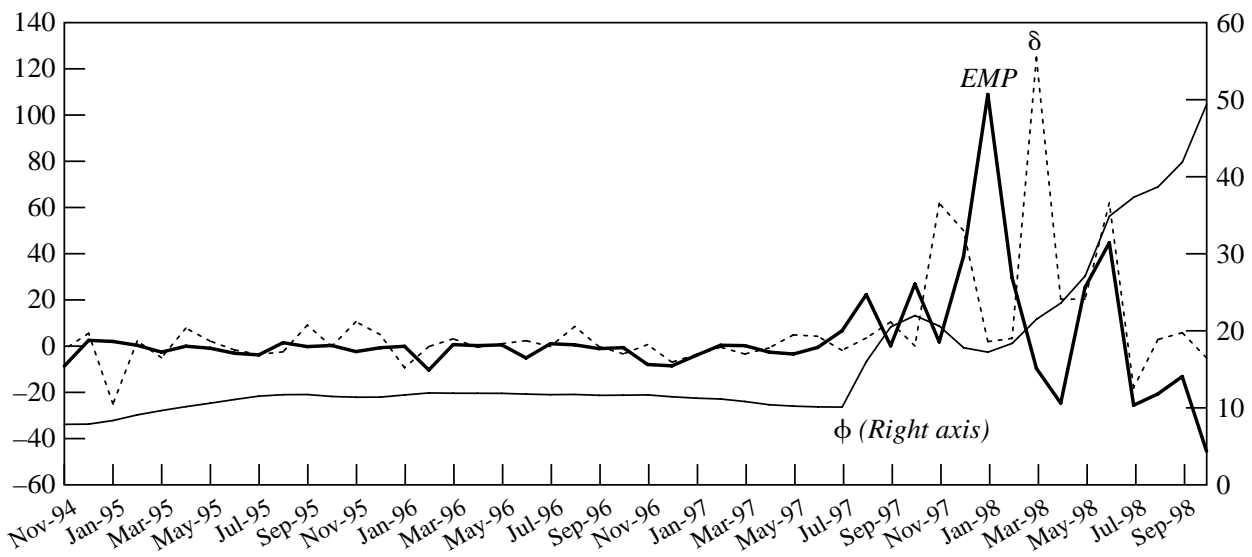

Korea

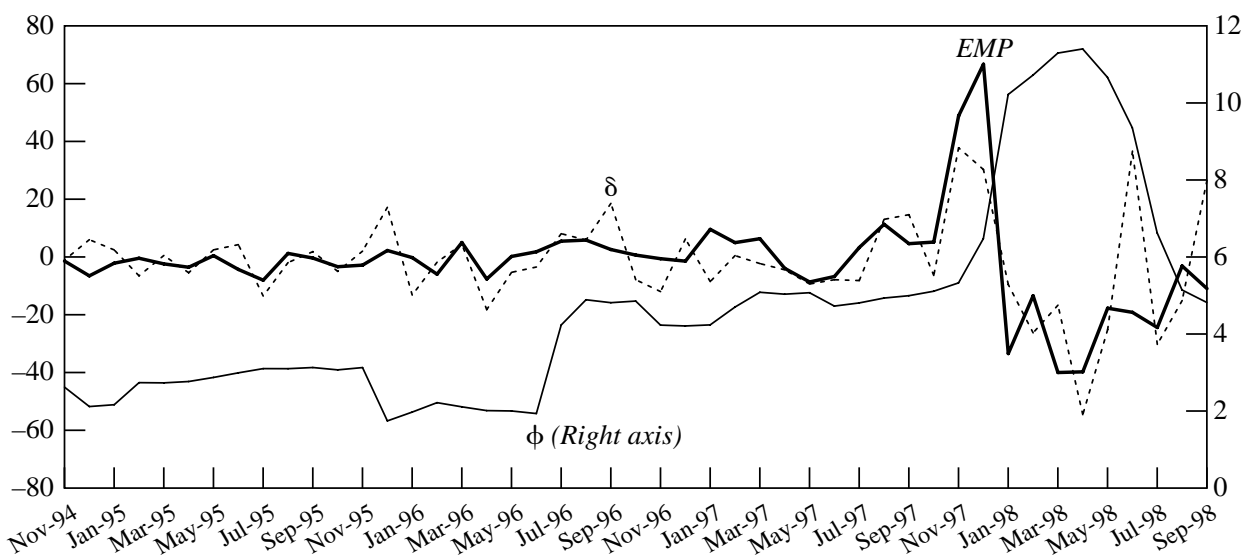

Thailand

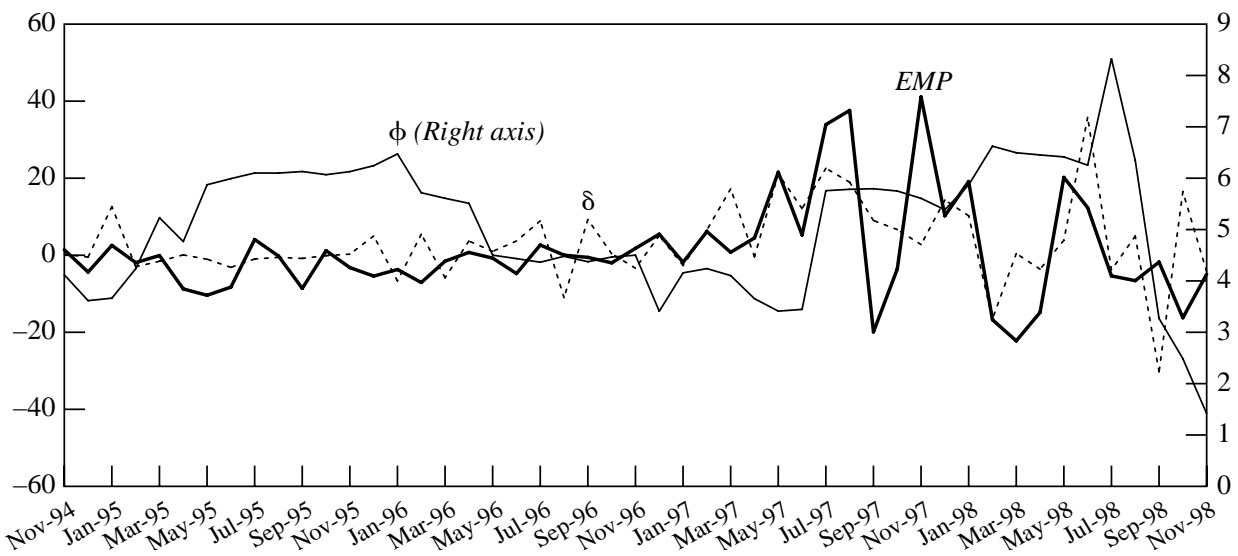

Note: EMP, domestic credit growth $(\delta)$, in percent per month, left axis. Interest differential $(\phi)$ in percent, right axis. 
Brazil was forced to defend their newly created currency, the real, in March 1995 (shortly after the Mexican crisis) by increasing $\phi$, even as both EMP and $\delta$ rose. Chile suffered less from the "tequila spillover" than many other Latin American countries. ${ }^{18}$ Nonetheless during mid-1995 as EMP rose, so did $\delta$, while $\phi$ fell.

In the selected Asian countries, EMP had been historically much lower than in Latin American countries. By the mid-1990s, there were growing financial fragilities (see Corsetti, Pesenti and Roubini, 1998; Lane and others, 1999; and Baliño and Ubide, 1999). Beginning in mid-1997 both EMP and $\delta$ rose, first in Thailand, next Indonesia, and then Korea, suggesting that the crises were foreshadowed by a period of loose monetary policy - gradually for several months and then more rapidly. In the aftermath of the crises, both $E M P$ and $\delta$ fell, while $\phi$ rose and generally remained high for several months thereafter.

Among Latin American countries, responses to the 1997-98 Asian events and to the 1998 Russian default varied. Mexico's response was to loosen monetary policy: as $E M P$ rose, so did $\delta$, while $\phi$ fell. By contrast, Brazil tightened: $E M P$ rose, $\delta$ fell, and $\phi$ rose. In Chile, as EMP rose, so did both $\delta$ and $\phi$.

\section{EMP and Monetary Policy: A Vector Autoregression Approach}

In this section, a vector autoregression (VAR) framework is developed to determine whether monetary policy affects $E M P$ in the direction presumed by standard monetary theory. A key feature of this framework is how monetary policy is modeled. In most recent research on industrialized countries, an interest rate is considered to be the policy variable. However, as discussed above, interest rates make a noisy indicator of monetary policy. For this reason, a compromise strategy is developed that includes both a monetary aggregate $(\delta)$ and the interest differential $(\phi)$. The system is: ${ }^{19}$

$$
X_{t}=a_{0}+a_{1} X_{t-1}+a_{2} X_{t-2}+\ldots .+v_{t}
$$

where $X=(\delta, E M P, \phi)$ is a matrix of variables, $a_{i}$ is a vector of coefficients, and $v_{t}=\left(v_{\delta}, v_{E}, v_{\phi}\right)$ is a vector of error terms. ${ }^{20} \mathrm{~A}$ system like (5) permits testing for effects of past values of $X$ on current values. Assumptions regarding the exogeneity of certain variables (like a policy variable) are easily incorporated into a system like (5). To do so, first assume that each element of the error vector $v_{t}$ is, in turn, composed of "own" error terms $w_{t}=\left(w_{\delta}, w_{E}, w_{\phi}\right)$ and contemporaneous correlations with "other" errors. That is:

$$
v_{t}=B w_{t}
$$

where $B$ is a $3 \times 3$ matrix whose diagonal elements (own correlations) equal one and whose nonzero off-diagonal elements reflect contemporaneous correlations

\footnotetext{
${ }^{18}$ On this point, see Edwards (1998).

${ }^{19}$ For industrialized countries, other studies that use a VAR methodology to examine monetary policy include Christiano and Eichenbaum (1992); Friedman and Kuttner (1992); Kashyap, Stien, and Wilcox (1993); Strongin (1995); and Bernanke and Mihov (1998).

${ }^{20}$ In all cases, $\phi$ is measured as the difference on deposit interest rates. For Mexico and Korea, since $\phi_{t}$ is nonstationary in levels but stationary in first differences, it is entered accordingly as $\Delta \phi$.
} 
among the error terms. Now, assumptions regarding the exogeneity of certain variables may be incorporated in restrictions on the matrix $B$ (i.e., ordering of the variables). ${ }^{21}$

As discussed above, the domestic credit growth variable $\delta$ is assumed to be exogenous. That is, in any period, innovations to $\delta$ (i.e., $v_{\delta}$ ) reflect only the tastes and preferences of the policymaker:

$$
v_{\delta t}=w_{\delta t}
$$

Next, shocks to exchange market pressure $\left(v_{E}\right)$ contain two elements: the "own" shock $\left(w_{E}\right)$ plus one related to innovations in domestic credit:

$$
v_{E t}=w_{E t}+b_{21} w_{\delta t}
$$

Thus, $w_{E}$ may be thought of as a shock to the demand for a country's currency, attributable perhaps to changes in investor confidence and sentiment. Thus, $b_{2 l} w_{\delta t}$ represents the portion of shocks to EMP that is contemporaneously correlated with domestic credit growth.

Finally, shocks to the change in the interest rate differential $\left(w_{\phi}\right)$ is the sum of three elements: the "own" shock $\left(w_{E}\right)$ plus the ones related to innovations in domestic credit and EMP:

$$
v_{\phi t}=w_{\phi t}+b_{31} w_{\delta t}+b_{32} w_{E t}
$$

According to equation (9), innovations to domestic credit $\mathrm{w}_{\delta}$ affect the interest rate differential through either standard liquidity or Fisher channels. Also, according to balance of payments crises models, the value of $b_{31}$ may itself depend on the whether market participants expect an exchange rate crisis. ${ }^{22}$ Thus, the predicted sign of $b_{31}$ is ambiguous. And, since the value of this parameter may depend on the exchange rate regime, estimates in the next section include tests for parameter stability. Second, the interest rate differential should respond to changes in EMP: a rise in EMP may signal either further exchange rate depreciation in the future, or additional risk, or both. Such effects are captured in the term $b_{32} w_{E t}$ and $b_{32}$ should be greater than zero. The "own" shock $w_{\phi}$ thus contains other factors not contained in either $w_{\delta}$ or $w_{E}$. This component should be thought of as a "hybrid" that potentially contains both policy- and market-determined elements. ${ }^{23}$

${ }^{21}$ To implement these restrictions, either a Choleski decomposition or a procedure like Bernanke's (1986) may be used. See also Enders (1995), Chapter 5. Of course, different assumptions about exogeneity imply different restrictions (i.e., orderings in a Choleski decomposition). However, as discussed in the next section, results were largely insensitive to alternative orderings.

${ }^{22}$ For example, Flood and Garber (1984) show that prior to an exchange rate crisis, but not after, the forward premium (FP) is a linear function of domestic credit: $\partial F P / \partial \delta(D)>0$ for $0<D<D^{*}$, where $D^{*}$ is the level of domestic credit that precipitates an exchange rate crisis. Note that in this context, the implied forward premium is $E\left\{\left[(1+i) /\left(1+i_{U S}\right)-1\right]\right.$, where $i$ and $i_{U S}$ are domestic and U.S. interest rates. Thus, for all $D, \partial \phi / \partial \delta=\partial F P / \partial \delta *\left(1+i_{U S}\right) / E$.

${ }^{23} \mathrm{An}$ alternative assumption would be for EMP to be contemporaneously determined by both $\delta$ and $\Delta \phi$. In this case, equation (8) would be rewritten as: $v_{E t}=w_{E t}+b_{21} w_{\delta t}+b_{23} w_{\phi t}$. Since $\phi$ reflects the opportunity cost of holding money, $b_{23}>0$. However, under this assumption, for the system also to be just identified, $b_{31}$ must be zero in equation (9). 


\section{Evan Tanner}

In addition to the contemporaneous relationships shown in equations (7) through (9), impulse response functions (IRFs) summarize the effect of past innovations (i.e., lagged elements of $w$ ) to current values of $X$. Thus, IRFs provide two additional ways to evaluate the effect of monetary policy on EMP. First, IRFs show effects on EMP of both current and past innovations to domestic credit $\left(w_{\delta}\right)$. Second, IRFs also show effects on EMP of past (but not current) innovations to the interest rate differential $\left(w_{\phi}\right)$. But, this latter IRF may only be thought of as a policy relationship insofar as innovations to the interest rate differential represent policy shocks. (Note also that IRFs show effects on $\phi$ of both current and past innovations to domestic credit and $E M P, w_{\delta}$ and $w_{E}$, respectively.)

However, the framework discussed above also helps to address the paper's third main question, namely, how the monetary policy stance is determined. Specifically, the IRFs provide a policy reaction function: they show effects on current $\delta$ of past (but not current) innovations to EMP $\left(w_{E}\right)$ and changes in the interest rate differential $\left(w_{\phi t}\right) .{ }^{24}$ For example, when faced by positive innovations to EMP (for example, a decrease in investor confidence) policymakers may respond "prudently" with contractionary policy (reducing $\delta$ ). However, policymakers might face pressures to act otherwise.

This is especially true if the authority attempts to defend the exchange rate during a financial panic. As investors reduce holdings of a country's currency, both financial system deposits and central bank reserves fall (EMP rises). At the same time, the central bank is also pressured to provide liquidity to the financial system, raising $\delta$. Such a sequence of events, in the context of balance of payments crises and speculative attacks, is discussed in several papers, including Flood, Garber, and Kramer (1996) and Calvo and Mendoza (1996).

\section{Estimation Results}

Individual country estimates, presented in this section, use data from 1990 through 1998. To focus on the recent crisis period, pooled estimates, using data from 1996 to 1998 , are also presented below. For both individual and pooled estimates, tests for stability of parameters, precrisis versus postcrisis, are presented. ${ }^{25}$

\section{Individual Country Estimates, 1990-98}

Estimation results, including adjusted $\mathrm{R}^{2} \mathrm{~s}$ and exclusion (Granger causality) tests are summarized in Table 1. IRFs (generated by the Choleski decomposition as discussed in Section II) and corresponding standard errors are presented in Tables 2 through $4 .{ }^{26}$

\footnotetext{
${ }^{24}$ Note that the issue addressed here is similar to that of exchange rate targeting. For example, Edwards and Savastano (1998) also estimate a policy reaction function for Mexico during the mid-1990s. However, they examine the effect of changes in the exchange rate (rather than EMP) on M1 (rather than domestic credit of the central bank).

${ }^{25}$ Estimations presented include 4 lags. Other lag lengths provided qualitatively similar results. For parameter stability tests, to obtain sufficient degrees of freedom, 2 lags were used.

${ }^{26} \mathrm{An}$ IRF summarizes the response of a variable in $X$ to a one-unit innovation in $w$.
} 
Shocks to the domestic credit growth variable $\left(w_{\delta}\right)$ are important for explaining EMP. The estimates suggest that shocks to $\delta$ affect EMP positively, as expected. As Table 1 shows, for four out of six countries (Indonesia, Korea, Thailand, Brazil) the hypothesis that lagged $\delta$ does not help explain current EMP is rejected at the 95 percent level or better. However, as Table 2 shows, for all countries, there are positive and significant IRFs for at least the current period (period 0). ${ }^{27}$ For all countries except Chile, the magnitude of the initial shock exceeds one. That is, a 1 percent shock to domestic credit leads to a change in exchange market pressure that exceeds 1 percent. For Indonesia, Thailand, and Brazil, there are lagged positive effects. Korea, however, presents an anomaly, as some lagged effects are negative and significant.

Some evidence also suggests that shocks to the interest differential $\left(w_{\phi}\right)$ affect $E M P$. However, this evidence is weaker than that linking EMP to $\delta$, above. Like domestic credit, (see Table 1) the hypothesis that lagged $\phi$ does not help explain current EMP is rejected at the 90 percent level or better in four out of six countries (Indonesia, Thailand, Brazil, Mexico). The IRFs in Table 2, though, provide somewhat weaker evidence than that for domestic credit growth $\delta$. For four out of six countries (Indonesia, Thailand, Brazil, and Mexico) there are significant IRFs for at least one period.

These effects are negative, suggesting that positive innovations in the domestic interest rate help increase and support the exchange rate (i.e., reduce $E M P)$. However, unlike the corresponding effects for $\delta$, these effects happen immediately in only two countries, Indonesia and Mexico. In Thailand, effects occur with a one-month lag, while in Brazil, effects take place after two months.

In most cases, shocks to EMP $\left(w_{E}\right)$ affect the interest differential positively. This should not be surprising, since an increase in EMP is generally associated with an increase in either expected exchange depreciation, risk, or both. For three of the six countries (Indonesia, Korea, Mexico) the hypothesis that EMP does not help explain current $\phi$ is rejected at the 95 percent level or better (as Table 1 shows). For all countries except Thailand, there are significant IRFs for at least one period (as Table 3 shows). Of these, responses are positive in Korea, Brazil, and Mexico. For Indonesia, there is an initial positive response whose $t$-statistic equals 1.98 , offset by a negative response after 3 months but a positive response after 6 months. For Chile, the initial response is negative.

Domestic credit shocks $\left(w_{\delta}\right)$ affect interest differentials $(\phi)$ negatively in some countries (consistent with a liquidity effect), but positively in others (consistent with a Fisher effect). Such a finding should not be surprising, given the theoretically ambiguous nature of the link between these two variables, as mentioned in the previous section. For four of the six countries (Indonesia, Korea, Thailand, and Brazil) the hypothesis that $\delta$ does not help explain current $\phi$ is rejected at the 95 percent level or better (see Table 1). For all countries except Mexico, there are significant responses for at least one period, as Table 3 shows. For Indonesia, Korea, Brazil, and Chile, the responses are positive, suggesting that the Fisher effect dominates the liquidity effect in these countries. (Such a response is not

${ }^{27} \mathrm{An}$ IRF is significant if its $t$-statistic exceeds |2|. 
Table 1. Summary of Estimates, Vector Autoregression System (5),

Eq. (5)

$$
X_{t}=a_{0}+a_{1} X_{t-1}+a_{2} X_{t-2}+\ldots .+v_{t}, \quad X=(\delta, \mathrm{EMP}, \phi)
$$

Individual Country Estimates, 1990-98 (monthly data)

$\begin{array}{lcccccc} & \text { Brazil } & \text { Chile } & \text { Mexico } & \text { Indonesia } & \text { Korea } & \text { Thailand } \\ \begin{array}{l}\text { Dependent Variable: } \delta \\ \text { F-Test, Exclusion of: }\end{array} & & & & & & \\ \text { Lagged } \delta & 34.65 & 2.78 & 2.15 & 1.70 & 10.04 & 1.11 \\ & (0.00) & (0.03) & (0.08) & (0.16) & (0.00) & (0.36) \\ \text { Lagged EMP } & 6.54 & 2.29 & 3.12 & 11.63 & 9.69 & 4.32 \\ & (0.00) & (0.07) & (0.02) & (0.00) & (0.00) & (0.00) \\ \text { Lagged } \phi & 33.12 & 2.55 & 1.05 & 2.09 & 1.47 & 0.46 \\ & (0.00) & (0.04) & (0.39) & (0.09) & (0.22) & (0.77) \\ & & & & & & \\ \mathrm{R}^{2} \text { Adjusted } & 0.87 & 0.11 & 0.05 & 0.43 & 0.43 & 0.10\end{array}$

\section{Dependent Variable: EMP}

$F$-Test, Exclusion of:

$\begin{array}{lcccccc}\text { Lagged } \delta & 4.04 & 0.34 & 0.70 & 6.46 & 3.22 & 3.55 \\ & (0.00) & (0.85) & (0.59) & (0.00) & (0.02) & (0.01) \\ \text { Lagged EMP } & 8.21 & 2.86 & 0.15 & 2.50 & 2.41 & 3.40 \\ & (0.00) & (0.03) & (0.96) & (0.05) & (0.06) & (0.01) \\ \text { Lagged } \phi & 5.82 & 0.65 & 2.78 & 6.71 & 1.83 & 2.12 \\ & (0.00) & (0.63) & (0.03) & (0.00) & (0.13) & (0.09) \\ & & & & & & \\ \mathrm{R}^{2} \text { Adjusted } & 0.64 & 0.03 & 0.03 & 0.49 & 0.28 & 0.16\end{array}$

Dependent Variable: $\phi$

$F$-Test, Exclusion of:

$\begin{array}{lcccccc}\text { Lagged } \delta & 16.50 & 1.10 & 0.39 & 12.23 & 2.37 & 2.07 \\ \text { Lagged EMP } & (0.00) & (0.36) & (0.81) & (0.00) & (0.06) & (0.09) \\ & 0.76 & 1.58 & 2.26 & 2.86 & 17.31 & 0.59 \\ \text { Lagged } \phi & (0.55) & (0.19) & (0.07) & (0.03) & (0.00) & (0.67) \\ & 25.97 & 25.64 & 4.00 & 16.48 & 1.50 & 1.27 \\ & (0.00) & (0.00) & (0.00) & (0.00) & (0.21) & (0.29) \\ \mathrm{R}^{2} \text { Adjusted } & 0.76 & 0.50 & 0.29 & 0.64 & 0.60 & 0.16\end{array}$

Note: For all estimates, 4 lags are used. $P$-statistics in parentheses. $\delta=$ growth of domestic credit (scaled by base money). EMP $=$ exchange depreciation plus reserves loss (scaled by base money). $\phi=$ change in interest differential. For Korea and Mexico, since $\phi$ is nonstationary, system includes first-difference $(\Delta \phi)$ instead. 
Table 2. Impulse Response Functions, Vector Autoregression System (5) Responses of EMP to shocks to domestic credit $\left(W_{\delta}\right)$ and interest differential $\left(w_{\phi}\right)$

\begin{tabular}{|c|c|c|c|c|c|c|}
\hline & Brazil & Chile & Mexico & Indonesia & Korea & Thailand \\
\hline \multicolumn{7}{|c|}{ Shock to $\delta$} \\
\hline Period 0 & $\begin{array}{c}2.18 \\
(2.39)\end{array}$ & $\begin{array}{c}0.73 \\
(2.95)\end{array}$ & $\begin{array}{l}13.84 \\
(8.77)\end{array}$ & $\begin{array}{c}2.29 \\
(2.30)\end{array}$ & $\begin{array}{c}4.62 \\
(5.19)\end{array}$ & $\begin{array}{c}4.61 \\
(6.35)\end{array}$ \\
\hline Period 1 & $\begin{array}{c}1.07 \\
(1.25)\end{array}$ & $\begin{array}{c}0.04 \\
(0.18)\end{array}$ & $\begin{array}{c}0.47 \\
(0.27)\end{array}$ & $\begin{array}{c}2.92 \\
(2.93)\end{array}$ & $\begin{array}{c}3.54 \\
(3.69)\end{array}$ & $\begin{array}{c}2.15 \\
(2.16)\end{array}$ \\
\hline Period 2 & $\begin{array}{c}0.66 \\
(0.92)\end{array}$ & $\begin{array}{c}0.04 \\
(0.16)\end{array}$ & $\begin{array}{c}-2.23 \\
(-1.29)\end{array}$ & $\begin{array}{c}3.27 \\
(2.65)\end{array}$ & $\begin{array}{c}0.50 \\
(0.47)\end{array}$ & $\begin{array}{c}1.89 \\
(1.69)\end{array}$ \\
\hline Period 3 & $\begin{array}{c}1.55 \\
(2.36)\end{array}$ & $\begin{array}{c}0.06 \\
(0.26)\end{array}$ & $\begin{array}{c}0.63 \\
(0.39)\end{array}$ & $\begin{array}{c}1.99 \\
(1.85)\end{array}$ & $\begin{array}{c}2.34 \\
(2.24)\end{array}$ & $\begin{array}{c}1.83 \\
(1.68)\end{array}$ \\
\hline Period 4 & $\begin{array}{c}0.50 \\
(0.69)\end{array}$ & $\begin{array}{c}0.10 \\
(0.48)\end{array}$ & $\begin{array}{c}-1.33 \\
(-0.67)\end{array}$ & $\begin{array}{c}-2.09 \\
(-1.84)\end{array}$ & $\begin{array}{c}-0.66 \\
(-0.71)\end{array}$ & $\begin{array}{c}2.03 \\
(1.65)\end{array}$ \\
\hline Period 5 & $\begin{array}{c}-0.93 \\
(-1.38)\end{array}$ & $\begin{array}{c}-0.05 \\
(-0.46)\end{array}$ & $\begin{array}{c}-1.82 \\
(-1.36)\end{array}$ & $\begin{array}{c}0.69 \\
(0.64)\end{array}$ & $\begin{array}{c}-1.98 \\
(-2.32)\end{array}$ & $\begin{array}{c}0.28 \\
(0.34)\end{array}$ \\
\hline \multicolumn{7}{|c|}{ Shock to $\phi$} \\
\hline Period 1 & $\begin{array}{c}1.11 \\
(1.35)\end{array}$ & $\begin{array}{c}0.31 \\
(1.29)\end{array}$ & $\begin{array}{c}-3.71 \\
(-2.09)\end{array}$ & $\begin{array}{c}-2.51 \\
(-2.65)\end{array}$ & $\begin{array}{c}0.58 \\
(0.69)\end{array}$ & $\begin{array}{c}-0.95 \\
(-1.20)\end{array}$ \\
\hline Period 2 & $\begin{array}{c}-0.31 \\
(-0.38)\end{array}$ & $\begin{array}{c}0.15 \\
(0.57)\end{array}$ & $\begin{array}{c}2.67 \\
(1.63)\end{array}$ & $\begin{array}{c}-1.20 \\
(-1.15)\end{array}$ & $\begin{array}{c}-1.63 \\
(-1.62)\end{array}$ & $\begin{array}{c}-2.02 \\
(-2.11)\end{array}$ \\
\hline Period 3 & $\begin{array}{c}-2.86 \\
(-3.20)\end{array}$ & $\begin{array}{c}-0.13 \\
(-0.51)\end{array}$ & $\begin{array}{c}-0.78 \\
(-0.40)\end{array}$ & $\begin{array}{c}-2.76 \\
(-2.72)\end{array}$ & $\begin{array}{c}-2.09 \\
(-1.91)\end{array}$ & $\begin{array}{c}-0.74 \\
(-0.73)\end{array}$ \\
\hline Period 4 & $\begin{array}{c}-4.22 \\
(-4.93)\end{array}$ & $\begin{array}{c}-0.14 \\
(-0.64)\end{array}$ & $\begin{array}{c}-2.96 \\
(-1.74)\end{array}$ & $\begin{array}{c}2.30 \\
(2.17)\end{array}$ & $\begin{array}{c}-1.05 \\
(-1.22)\end{array}$ & $\begin{array}{c}1.68 \\
(1.65)\end{array}$ \\
\hline Period 5 & $\begin{array}{c}-3.06 \\
(-3.69)\end{array}$ & $\begin{array}{c}-0.06 \\
(-0.29)\end{array}$ & $\begin{array}{c}-0.60 \\
(-0.48)\end{array}$ & $\begin{array}{c}3.74 \\
(3.15)\end{array}$ & $\begin{array}{c}-0.01 \\
(-0.01)\end{array}$ & $\begin{array}{c}0.63 \\
(0.75)\end{array}$ \\
\hline Period 6 & $\begin{array}{l}-2.80 \\
(-3.37)\end{array}$ & $\begin{array}{l}-0.11 \\
(-0.69)\end{array}$ & $\begin{array}{c}0.19 \\
(-0.18)\end{array}$ & $\begin{array}{c}2.02 \\
(1.86)\end{array}$ & $\begin{array}{c}0.00 \\
(0.00)\end{array}$ & $\begin{array}{l}-0.63 \\
(-0.93)\end{array}$ \\
\hline
\end{tabular}

Note: $T$-statistics in parentheses.

surprising for Brazil and Chile, where inflation rates are typically higher than in the Asian countries).

As a policy reaction function, in most cases, EMP shocks $\left(w_{E}\right)$ affect domestic credit $(\delta)$ positively. For four of the six countries (Indonesia, Korea, Thailand, and Brazil) the hypothesis that lagged EMP does not help explain current $\delta$ is rejected at the 99 percent level or better, as Table 1 shows. Moreover, for all there are significant responses for at least one period, as shown in Table 4. In all cases, these are positive, suggesting that the authorities respond, on average, to increased EMP by providing additional liquidity to the banking system (rather than contracting the money supply). Note, however, that responses for Brazil and Chile come later than for the other countries (after 3 months). Note also that among all countries, responses for Chile are the weakest. By contrast, there are relatively strong responses within two months for Indonesia, Korea, Thailand, and Mexico. 
Table 3. Impulse Response Functions, Vector Autoregression System (5)

Responses of Interest Differential $(\Delta \phi)$ to shocks to domestic credit $\left(w_{\delta}\right)$ and $\operatorname{EMP}\left(w_{\mathrm{E}}\right)$

$\begin{array}{lcccccc} & \text { Brazil } & \text { Chile } & \text { Mexico } & \text { Indonesia } & \text { Korea } & \text { Thailand } \\ \text { Shock to } \delta & & & & & & \\ \text { Period 0 } & 1139.11 & 0.33 & 0.93 & 0.18 & -0.04 & -0.95 \\ & (3.37) & (0.50) & (3.97) & (2.45) & (-1.13) & (-1.20) \\ \text { Period 1 } & 753.51 & 0.02 & 0.91 & -0.06 & 0.04 & -2.02 \\ & (1.96) & (0.03) & (3.52) & (-0.61) & (0.83) & (-2.11) \\ \text { Period 2 } & 2001.58 & -0.27 & 0.25 & 0.05 & 0.14 & -0.74 \\ & (6.42) & (-0.35) & 0.95) & (0.43) & (2.87) & (-0.73) \\ \text { Period 3 } & 827.85 & -0.88 & 0.33 & 0.40 & 0.04 & 1.68 \\ & (2.89) & (-1.06) & (1.30) & (3.91) & (0.69) & (1.65) \\ \text { Period 4 } & -157.70 & -1.49 & 0.39 & 0.20 & 0.17 & 0.63 \\ & (-0.64) & (-1.77) & (1.33) & (2.29) & (2.99) & (0.75) \\ \text { Period 5 } & -65.31 & -0.96 & -0.26 & 0.21 & 0.12 & -0.63 \\ & (-0.29) & (-1.53) & -(1.18) & (2.23) & (2.38) & (-0.93) \\ \text { Shock to EMP } & & & & & & \\ \text { Period 1 } & 803.81 & -1.42 & 0.48 & 0.14 & -0.02 & -0.04 \\ & (2.59) & (-2.24) & (2.08) & (1.98) & (-0.38) & (-0.54) \\ \text { Period 2 } & 319.09 & 0.59 & 0.53 & 0.01 & 0.27 & -0.08 \\ & (0.84) & (0.67) & (1.79) & (0.16) & (6.04) & (-1.19) \\ \text { Period 3 } & 19.84 & 0.21 & 0.19 & -0.19 & 0.23 & 0.04 \\ & (0.05) & (0.23) & (0.75) & (-2.23) & (4.64) & (0.62) \\ \text { Period 4 } & -15.08 & -0.62 & 0.78 & -0.12 & 0.12 & 0.07 \\ & (-0.03) & (-0.68) & (2.74) & (-1.39) & (1.88) & (1.08) \\ \text { Period 5 } & -129.44 & -0.64 & 0.22 & 0.15 & 0.09 & -0.11 \\ & (-0.29) & (-0.69) & (0.71) & (1.73) & (1.41) & (-1.64) \\ \text { Period 6 } & 383.85 & -0.38 & -0.28 & 0.37 & 0.05 & -0.01 \\ & (0.95) & (-0.43) & -(1.22) & (3.66) & (0.80) & (-0.28) \\ & & & & & & \end{array}$

Note: $T$-statistics in parentheses.

In the case of Mexico, findings here confirm one of the key elements of the 1994-95 crisis, namely, sterilization of reserve outflows by the monetary authority (see Flood, Garber, and Kramer, 1996). ${ }^{28}$ Moreover, these finding suggest that, in Asia, like Mexico, such sterilization also occurred.

Evidence regarding responses of $\delta$ to interest differential shocks $(\phi)$ is weaker than that regarding $\delta$ and EMP above. For three of the six countries (Indonesia, Brazil, Chile) the hypothesis that lagged $\phi$ does not help explain current $\delta$ is rejected at the 99 percent level or better (see Table 1). However, the direction of the responses is mixed, as Table 4 shows. In both Chile and Brazil, there are positive and significant responses after one month. That is, in these cases, the authorities respond to higher interest rates with higher growth to domestic credit.

\footnotetext{
${ }^{28}$ Indeed, this finding is somewhat stronger than that of Calvo and Mendoza (1996), who report that, while domestic credit growth Granger causes reserve outflows, the reverse is not true.
} 
Table 4. Impulse Response Functions, Vector Autoregression System (5) Responses of Domestic Credit Growth $(\delta)$ to shocks to EMP $\left(W_{E}\right)$ and interest differential $\left(w_{\phi}\right)$

$\begin{array}{lcccccc} & \text { Brazil } & \text { Chile } & \text { Mexico } & \text { Indonesia } & \text { Korea } & \text { Thailand } \\ \text { Shock to EMP } & & & & & & \\ \text { Period 1 } & 6.44 & -0.09 & 1.62 & 0.35 & 5.44 & 2.37 \\ & (1.61) & (-0.54) & (1.00) & (0.31) & (5.20) & (3.43) \\ \text { Period 2 } & 3.60 & -0.26 & 5.29 & 7.04 & -0.41 & 0.34 \\ & (0.87) & -(1.51) & (3.45) & (5.25) & (-0.37) & (0.44) \\ \text { Period 3 } & 13.71 & 0.46 & 0.01 & 2.02 & -1.51 & -1.06 \\ & (2.59) & (2.67) & (0.01) & (1.63) & (-1.31) & (-1.41) \\ \text { Period 4 } & -2.16 & -0.07 & -1.91 & 1.86 & -0.95 & 0.12 \\ & (-0.39) & (-0.37) & (-1.22) & (1.40) & (-0.69) & (0.17) \\ \text { Period 5 } & 10.38 & -0.03 & -0.80 & 1.64 & -2.99 & 0.05 \\ & (2.05) & (-0.32) & (-0.72) & (1.41) & (-2.66) & (0.10) \\ \text { Period 6 } & 4.28 & -0.06 & -0.27 & 2.13 & -1.49 & 0.15 \\ & (0.78) & (-0.56) & (-0.25) & (1.85) & (-1.49) & (0.34) \\ & & & & & & \\ \text { Shock to } \phi & & & & & & \\ \text { Period 1 } & 8.77 & 0.47 & 0.44 & -1.24 & 0.15 & 0.59 \\ & (2.11) & (3.20) & (0.27) & (-0.92) & (0.19) & (0.83) \\ \text { Period 2 } & -5.95 & 0.13 & -0.21 & -1.85 & 0.88 & -1.11 \\ & (-1.44) & (0.81) & (-0.14) & (-1.55) & (0.85) & (-1.36) \\ \text { Period 3 } & -31.56 & 0.06 & -1.76 & 1.76 & -2.75 & -0.66 \\ & (-6.68) & (0.37) & (-1.02) & (1.25) & (-2.73) & (-0.91) \\ \text { Period 4 } & -23.50 & -0.10 & -1.70 & -1.71 & -2.15 & 0.16 \\ & (-4.49) & (-0.75) & (-1.26) & (-1.13) & (-2.27) & (0.20) \\ \text { Period 5 } & -21.31 & -0.01 & -0.19 & -3.77 & 0.75 & 0.63 \\ & (-3.99) & (-0.13) & (-0.18) & (-3.03) & (1.05) & (1.24) \\ \text { Period 6 } & -22.02 & -0.10 & -0.20 & 1.54 & 0.03 & 0.46 \\ & (-3.97) & (-1.02) & (-0.21) & (1.26) & (0.04) & (0.97) \\ & & & & & & \end{array}$

Note: $T$-statistics in parentheses.

In Brazil, however, there are strong negative effects after 3 months. Also, in Indonesia, there is a negative effect, but with a 5-month lag.

As discussed in Section II, parameters may not be stable over time, and may vary according to whether the exchange rate is fixed or floating. To address this issue, Sims's (1980) likelihood ratio statistic (see also Hamilton, 1994, pp. 297-99) yields a test for the stability of estimates for countries whose fixed (or tightly pegged) exchange rate becomes more flexible after a crisis, namely Indonesia, Korea, Mexico, and Thailand. ${ }^{29}$ This test statistic did not exceed the 90

${ }^{29}$ That is, dummy interacts on lagged values of $X$ are included the unrestricted version of the regression. Insufficient observations prevent this test from being applied to Brazil. Sims' (1980) statistic is $\lambda=(T-k)\left\{\log \left|\Omega_{R}\right|-\log \left|\Omega_{U}\right|\right\}$, where $T=$ total observations minus lags, $k=1+n p, n=$ number of variables, $p=$ number of parameters per equation, and $\Omega_{R}$ and $\Omega_{U}$ are the variance-covariance matrices for the restricted and unrestricted versions of the regression, respectively. The statistic is distributed $\chi^{2}$ with degrees of freedom (d.f.) equal to the number of restrictions. Since there are 3 variables, 2 lags, and 3 equations, d.f. $=18$. Thus, critical values for $\lambda$ are 26.0 (90 percent) and 28.9 (95 percent). Values of $\lambda$ are: Mexico, 5.57; Indonesia, 4.12; Korea, 7.94; and Thailand, 4.86. 


\section{Evan Tanner}

percent critical value for any country. Thus, there is no statistically significant difference in the precrisis and postcrisis parameters.

\section{Pooled Estimates, 1996-98}

Unlike individual country estimates, pooled estimates can provide a sense of the average relationships among the variables during the recent round of crises. Results of pooled estimates for the recent period (1996-98) including adjusted $\mathrm{R}^{2} \mathrm{~s}$, exclusion (Granger causality) tests, and impulse response functions (with corresponding standard errors) are summarized in Table 5. ${ }^{30}$ Impulse response functions and their corresponding standard errors are also presented visually, in Figures 2 through 7.

Like individual country estimates, shocks to the credit variable $(\delta)$ are positively associated with movements in EMP. As Part A of Table 5 shows, the hypothesis that lagged $\delta$ do not help explain current $E M P$ is rejected at better than the 99 percent level (with an $F$-statistic of 5.08). And, as Part B of the same table shows (see also Figure 2), there is a positive and significant contemporaneous response: a 1 percent shock to domestic credit leads to a change in exchange market pressure that exceeds 5 percent, consistent with individual country estimates.

Unlike individual country estimates, the evidence suggests that shocks to the interest differential $(\Delta \phi)$ do not affect EMP. As Part A of Table 5 shows, the hypothesis that lagged $\Delta \phi$ do not help explain current EMP is not rejected at conventional levels. And, as Part B of the same table shows (see also Figure 3), there are no significant impulse response functions.

Like individual country estimates, some evidence suggests that shocks to EMP affect the interest differential positively. As Part A of Table 5 shows, the hypothesis that EMP does not help explain current $\Delta \phi$ is not rejected at conventional levels. However, as Part B shows (see also Figure 4), there are significant, positive responses, after four months.

Some evidence also suggests that domestic credit shocks $(\delta)$ affect interest differentials $(\Delta \phi)$ positively (consistent with a Fisher effect). The hypothesis that $\delta$ does not help explain current $\Delta \phi$ is not rejected at conventional levels (Part A, Table 5). However, there are significant, positive responses after three months (Part B, Table 5, and Figure 5).

As is the case for most individual country estimates, EMP shocks affect domestic credit $(\delta)$ positively. As Part A of Table 5 shows, the hypothesis that lagged $E M P$ does not help explain current $\delta$ is rejected at better than the 99 percent level (with an $F$-statistic of 10.65). And, as Part B of the same table shows (see also Figure 6), there are significant, positive responses after one month.

However, $\delta$ does not appear to respond to interest differential shocks $(\Delta \phi)$. As Part A of Table 5 shows, the hypothesis that lagged $\Delta \phi$ does not help explain current $\delta$ is not rejected at conventional levels. And, as Part B of the same table shows (see also Figure 7), there are no significant responses.

\footnotetext{
${ }^{30}$ Estimates include country intercepts, not reported. In the pooled estimates, the interest differential is entered as a first difference $(\Delta \phi)$ for all countries.
} 
Table 5. Summary of Estimates, Vector Autoregression System (5)

$$
X_{t}=a_{0}+a_{1} X_{t-1}+a_{2} X_{t-2}+\ldots .+v_{t}, \quad \mathrm{X}=(\delta, \mathrm{EMP}, \Delta \phi)
$$

Pooled Estimates, 1996-98 (monthly data)

A. F-Tests for Exclusion ( $P$-statistics in parentheses)

Dependent Variable:

F-Test, Exclusion of:

Lagged $\delta$

Lagged EMP

Lagged $\Delta \phi$

$\mathrm{R}^{2}$ Adjusted $\delta$

2.16

(0.08)

10.65

(0.00)

1.28

(0.28)

0.21
EMP

\subsection{8}

(0.00)

8.63

(0.00)

0.45

(0.78)

0.18
$\Delta \phi$

1.03

(0.39)

0.79

(0.53)

122.31

(0.00)

0.89

B. Impulse Response Functions ( $t$-statistics in parentheses)

\begin{tabular}{lcccccc} 
Responses of: & \multicolumn{2}{c}{ EMP } & \multicolumn{2}{c}{$\Delta \phi$} & & \\
Shock to: & $\delta$ & & & & & \\
& & & & & & \\
& & & & & & \\
Period 0 & 5.07 & - & 0.07 & 0.10 & - & - \\
& $(5.48)$ & - & $(0.42)$ & $(0.58)$ & - & - \\
Period 1 & 0.71 & -1.29 & 0.41 & 0.34 & 4.43 & -0.89 \\
& $(0.64)$ & $(-1.32)$ & $(1.78)$ & $(1.46)$ & $(3.56)$ & $(-0.71)$ \\
Period 2 & 1.36 & -0.41 & 0.48 & 0.52 & 6.15 & 2.42 \\
& $(1.23)$ & $(-0.41)$ & $(1.82)$ & $(1.98)$ & $(4.89)$ & $(1.97)$ \\
Period 3 & -1.03 & -0.18 & 0.68 & 0.55 & 1.82 & -0.98 \\
& $(-0.99)$ & $(-0.18)$ & $(2.32)$ & $(1.71)$ & $(1.46)$ & $(-0.72)$ \\
Period 4 & -2.96 & 0.08 & 0.83 & 0.75 & 2.49 & -0.67 \\
& $(-2.95)$ & $(0.13)$ & $(2.69)$ & $(2.09)$ & $(2.07)$ & $(-0.71)$ \\
Period 5 & -0.51 & -0.42 & 0.65 & 0.93 & 1.41 & 0.49 \\
& $(-0.85)$ & $(-0.58)$ & $(2.17)$ & $(2.61)$ & $(1.56)$ & $(0.52)$ \\
Period 6 & 0.24 & -0.70 & 0.58 & 0.90 & -0.19 & -0.37 \\
& $(0.43)$ & $(-1.14)$ & $(1.97)$ & $(2.71)$ & $(-0.22)$ & $(-0.49)$
\end{tabular}

Like individual country estimates, the stability of parameters before and after crisis periods is examined with the Sims's (1980) statistic. As before, the value of this test statistic was below the 90 percent critical value, so the hypothesis of equality between precrisis and postcrisis parameters is not rejected. Also, IRF results were, for the majority of cases, insensitive to the ordering of variables in the Choleski decomposition. However, for those cases where EMP was entered first (implausibly assuming that $E M P$ is an exogenous variable) $\delta$ failed to cause the expected, positive response in EMP.

\section{Policy Implications and Conclusions}

This paper has examined the relationship between EMP and monetary policy during the 1990s in several emerging market economies, namely, Brazil, Chile, 
Figure 2. Response of EMP to One Unit Shock to Credit Growth ( $\delta$ ) (in percent)

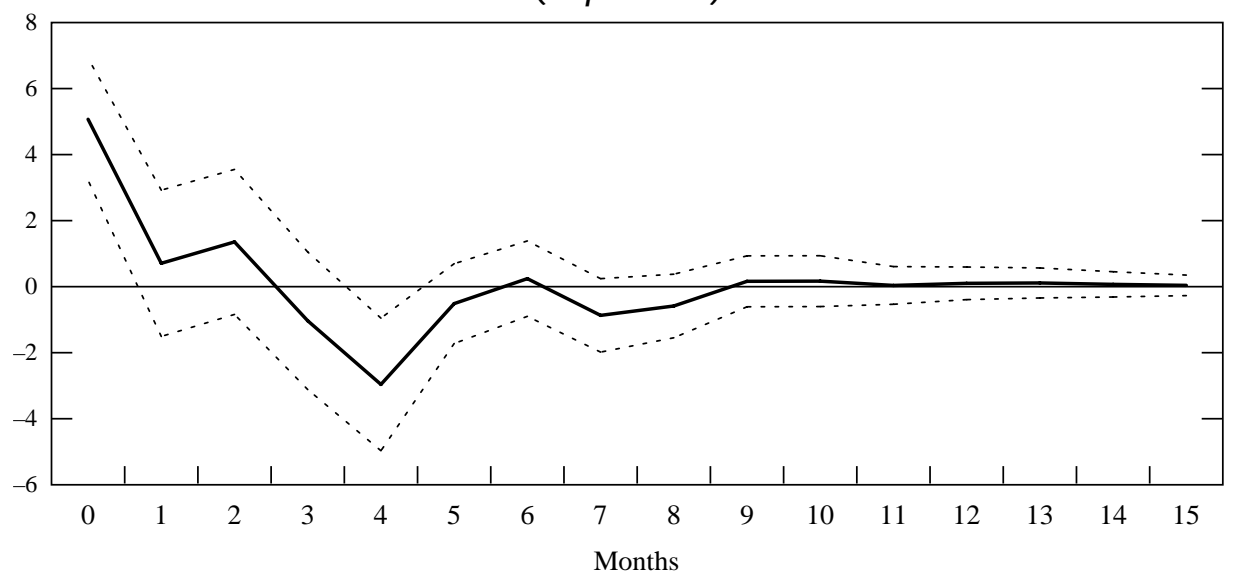

Figure 3. Response of EMP to One Unit Shock to Interest Differential $(\Delta \phi)$ (in percent)

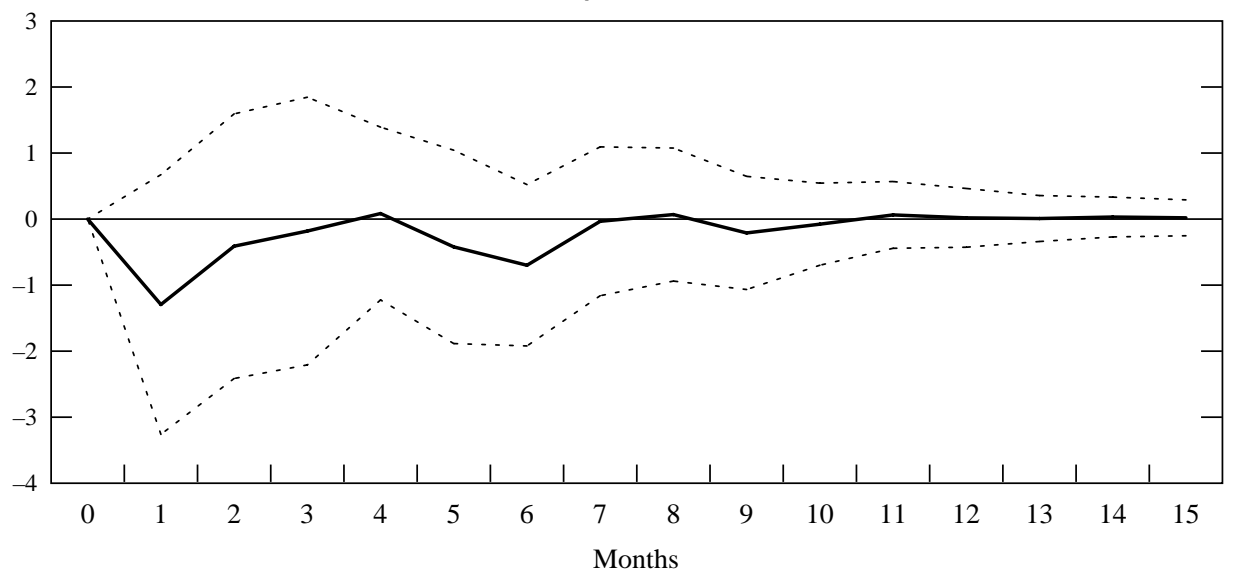

Figure 4. Response of Interest Differential $(\Delta \phi)$ to One Unit Shock to EMP (in percent)

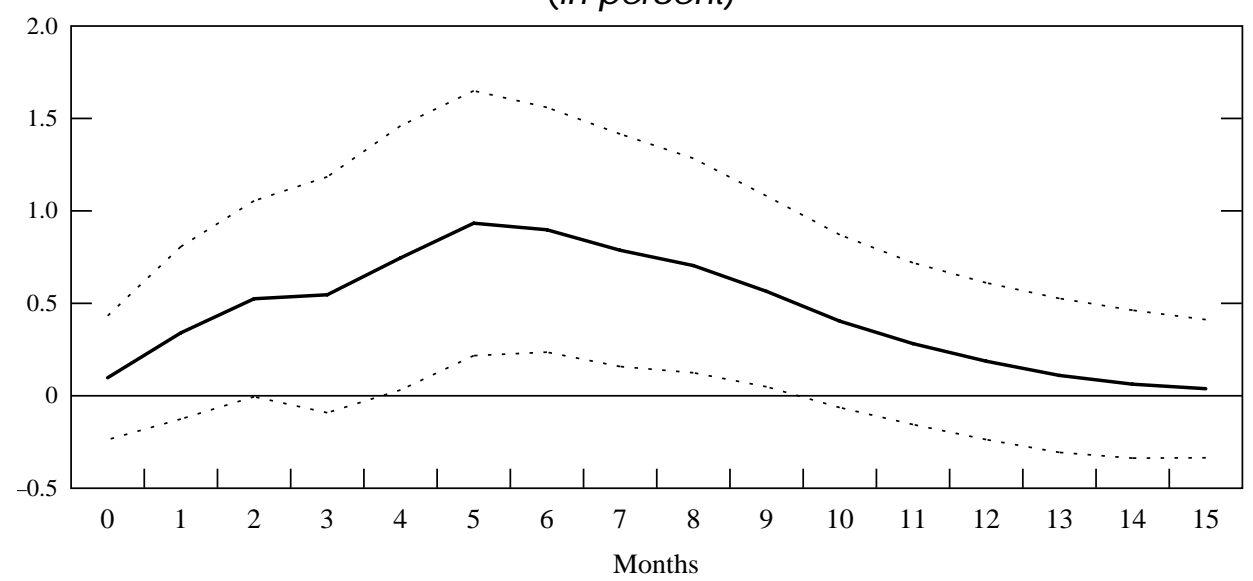

Note: Dotted lines are 2-times standard errors. 
Figure 5. Response of Interest Differential $(\Delta \phi)$ to One Unit Shock to Credit Growth $(\delta)$

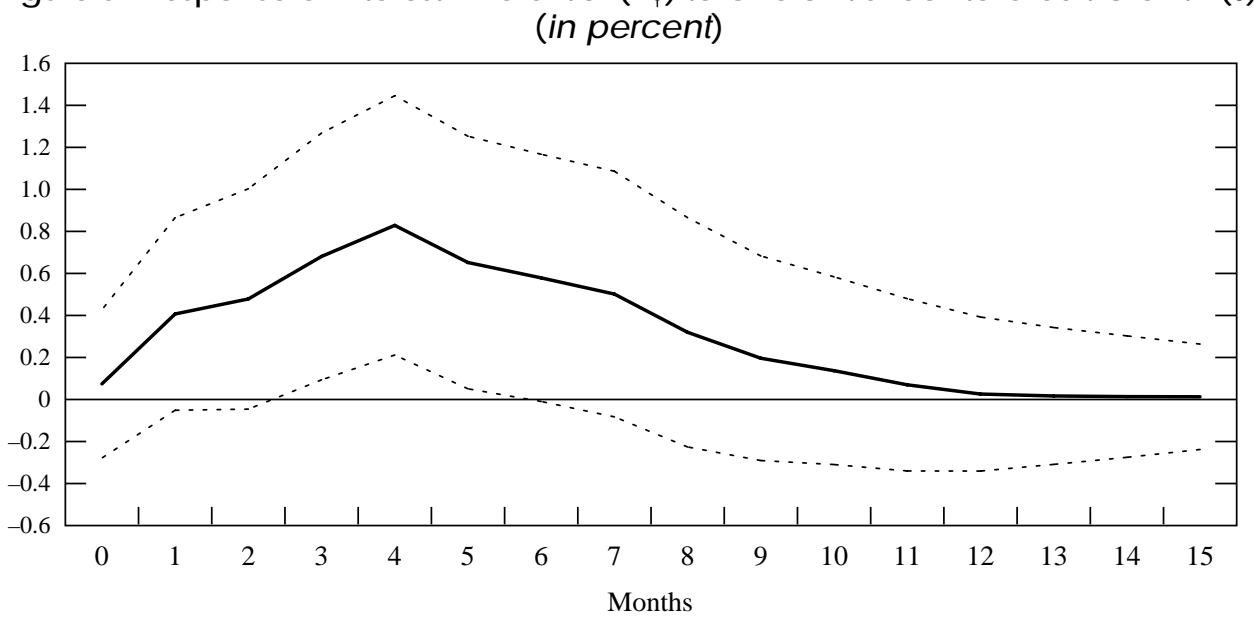

Figure 6. Response of Credit Growth ( $\delta$ ) to One Unit Shock to EMP (in percent)

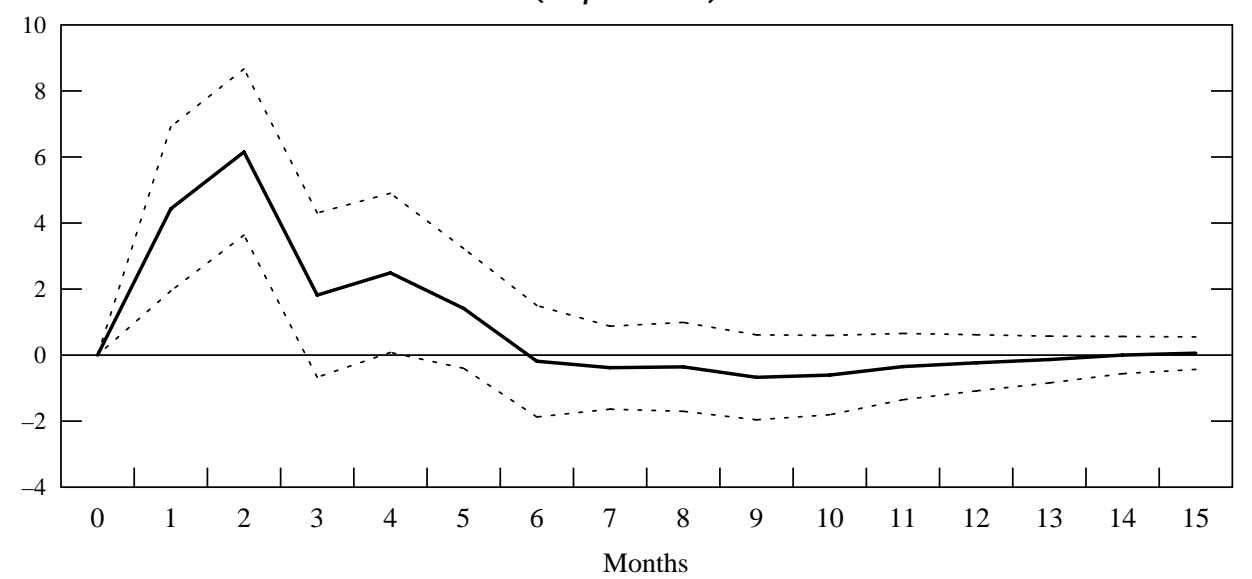

Figure 7. Response of Credit Growth $(\delta)$ to One Unit Shock to Interest Differential $(\Delta \phi)$ (in percent)

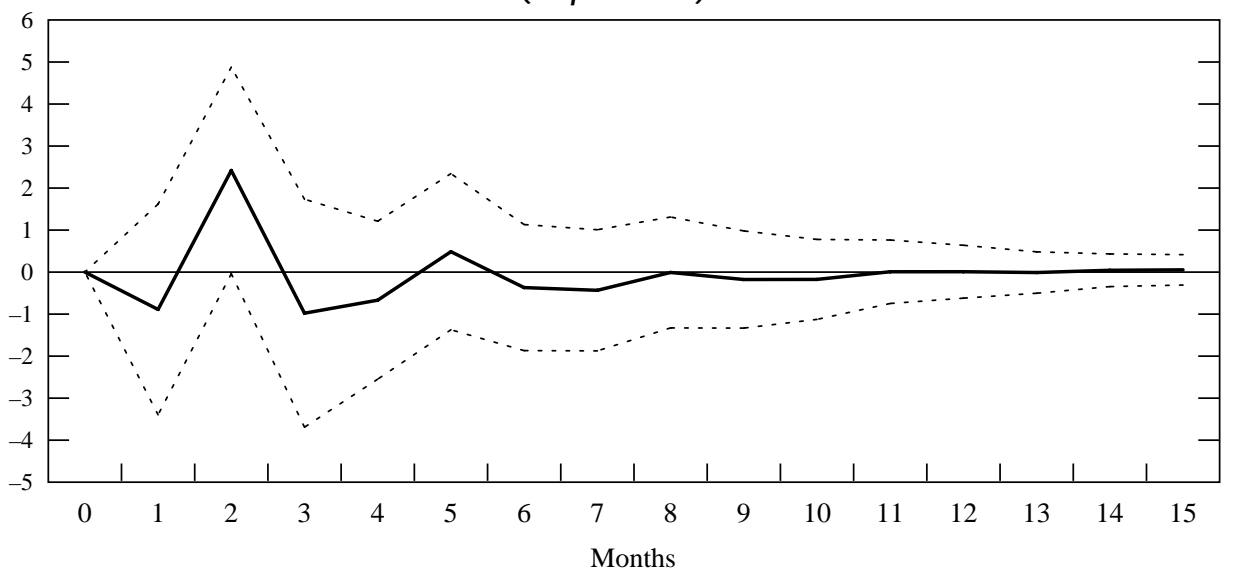

Note: Dotted lines are 2-times standard errors. 


\section{Evan Tanner}

Mexico, Indonesia, Korea, and Thailand. Because exchange rate regimes in these economies were neither perfectly fixed nor free floating, it would be misleading to focus exclusively on either reserve or exchange rate movements. Rather, EMP is more appropriate, as it summarizes the difference between the growth rates of money supply and demand under managed exchange rate regimes.

Evidence was presented that one measure of monetary policy, domestic credit growth, has powerful impacts on EMP in the "right" direction: a reduction in the domestic credit component of the money supply helps to reduce EMP (either by increasing the value of a country's currency, or its stock of international reserves, or both). This finding held for both individual country and pooled estimates. This finding also supports evidence by Goldfajn and Gupta (1998) that contractionary monetary policy helps support the exchange rate, but not work by Radetlet and Sachs (1998) and Furman and Stiglitz (1998), whose research finds the opposite.

In a related vein, evidence regarding the response of EMP to interest shocks was somewhat weaker than that linking EMP and domestic credit growth. There is some evidence from some individual countries (but not from pooled estimates) that positive interest differential shocks also help to reduce EMP. This finding, however, should not cast doubt on the effectiveness of monetary policy for affecting EMP. Rather, this finding underscores the fact that interest rates have market-determined (as well as policy-determined) elements. ${ }^{31}$

Some insights were also provided into the determinants of interest differentials. There is some evidence, both from individual country and pooled estimates, that shocks to EMP positively affect interest rates. This makes sense, given that higher EMP may signal both exchange depreciation and risk. However, the effect of domestic credit shocks on the interest differential works positively for higher inflation countries like Brazil and Chile (reflecting a Fisher effect) and for the pooled estimates, but negatively for lower inflation countries like Korea and Thailand (reflecting a liquidity effect).

Finally, the paper provided some evidence (in both individual country and pooled estimates) that monetary authorities respond to increases of EMP by expanding rather than contracting domestic credit, a finding discussed by others in the context of the 1994-95 Mexican crisis.

Such a policy reaction may represent an error in perception that results in a vicious circle, since an initial rise in EMP may be due to a fall in money demand that the central bank incorrectly perceives to be temporary. However, such a policy may also reflect a weak financial system. In both Mexico and Asia, such weakness was evident prior to the crises. Nonperforming assets in the financial system represent implicit liabilities of the public sector. Because compensating fiscal adjustments did not occur before the crises, and it was politically impossible to let unsound institutions fail, policymakers may have had few alternatives other than to extend credit to such institutions, even though it was destabilizing. Put differently, prior to the crises, monetary policies were "too loose" in a systematic way.

\footnotetext{
${ }^{31}$ Also, the policymaker and the econometrician have two distinct data sets. For the econometrician, it is often difficult to distinguish between policy- and market-determined components of interest rates.
} 
Other preventative measures, and a different political environment, may have provided central bankers with more options.

\section{REFERENCES}

Ahluwalia, Pavan, 2000, "Discriminating Contagion: An Alternative Explanation of Contagious Currency Crises in Emerging Markets," IMF Working Paper 00/14 (Washington: International Monetary Fund).

Baliño, Tomás, and Angel Ubide, 1999, “The Korean Financial Crisis of 1997: A Strategy of Financial Sector Reform” IMF Working Paper 99/28 (Washington: International Monetary Fund).

Basurto, Gabriela and Atish Ghosh, 2000, "The Interest Rate: Exchange Rate Nexus in Asian Crisis Countries," IMF Working Paper 00/19 (Washington: International Monetary Fund).

Bernanke, Ben, 1986, "Alternative Explanations of the Money-Income Correlation," in Real Business Cycles, Real Exchange Rates, and Actual Policies, ed. by K. Brunner and A. Meltzer, Carnegie Rochester Series on Public Policy No. 25.

and Alan Blinder, 1992, "The Federal Funds Rate and the Channels of Monetary Transmission," American Economic Review Vol. 82, pp. 901-21.

_ and Ilian Mihov, 1998, A Measuring Monetary Policy," Quarterly Journal of Economics, August, pp. 869-902.

Brissimis, Sophocles N., and John A. Leventakis, 1984, "An Empirical Inquiry into the ShortRun Dynamics of Output, Prices and Exchange Market Pressure," Journal of International Money and Finance, Vol. 3, pp. 75-89.

Burkett, Paul and Donald G. Richards, 1993, "Exchange Market Pressure in Paraguay, 1963-88: Monetary Disequilibrium Versus Global and Regional Dependency." Applied Economics, Vol. 25, pp. 1053-63.

Calvo, Guillermo, and Enrique Mendoza, 1996, "Mexico's Balance-of-Payments Crisis: A Chronicle of a Death Foretold," Journal of International Economics, Vol. 41, pp. 235-64.

Christiano, Lawrence, 1995, "Resolving the Liquidity Effect," Federal Reserve Bank of St. Louis, Review, Vol. 77, pp. 55-61.

Christiano, Lawrence and Martin Eichenbaum, 1992, "Identification and the Liquidity Effect of a Monetary Policy Shock," in Political Economy, Growth, and Business Cycles, ed. by A. Cukierman, Z. Hercowitz, and L. Leiderman (Cambridge, Massachusetts: MIT Press).

Christiano, Lawrence, Martin Evans, and Martin Eichenbaum, 1998, "Monetary Policy Shocks: What Have we Learned and to What End?" NBER Working Paper 6400 (Cambridge, Massachusetts: National Bureau of Economic Research).

Connolly, Michael and Jose Dantas da Silveira, 1979, "Exchange Market Pressure in Postwar Brazil: An Application of the Girton-Roper Monetary Model," American Economic Review; Vol. 69, pp. 448-54.

Corsetti, Giancarlo, Paolo Pesenti, and Nouriel Roubini, 1998, "What Caused the Asian Currency and Financial Crisis? Part II: The Policy Debate, “ NBER Working Paper 6834 (Cambridge, Massachusetts: National Bureau of Economic Research).

Edwards, Sebastian, 1998, "Interest Rate Volatility, Capital Controls, and Contagion," NBER Working Paper 6756 (Cambridge, Massachusetts: National Bureau of Economic Research). - and Miguel Savastano, 1998, "The Morning After: The Mexican Peso in the Aftermath of the 1994 Currency Crisis" NBER Working Paper 6516 (Cambridge, Massachusetts: National Bureau of Economic Research). 


\section{Evan Tanner}

Eichengreen, Barry, Andrew Rose, and Charles Wyplosz, 1996, "Contagious Currency Crises: First Tests," Scandinavian Journal of Economics, Vol. 98, pp. 463-84.

Enders, Walter, 1995, Applied Econometric Time Series (New York: John Wiley and Sons).

Flood, Robert and Peter Garber, 1984, "Collapsing Exchange Rate Regimes: Some Linear Examples," Journal of International Economics, Vol. 17, pp. 1-13.

Flood, Robert, Peter Garber, and Charles Kramer, 1996, "Collapsing Exchange Rate Regimes: Another Linear Example," Journal of International Economics, Vol. 41, pp. 223-34.

Friedman, Benjamin and Kenneth Kuttner, 1992, "Money, Income, Prices, and Interest Rates," American Economic Review, Vol. 82, pp. 472-92.

Furman, Jason and Joseph Stiglitz, 1998, "Economic Crises: Evidence and Insights from East Asia," (unpublished; Washington: World Bank). Presented at Brookings Panel on Economic Activity, Sept. 4, 1998.

Ghosh, Atish R. and Steven Phillips, 1999, "Monetary and Exchange Rate Policies," in IMFSupported Programs in Indonesia, Korea, and Thailand: A Preliminary Assessment, IMF Occasional Paper 178, Chapter 6 (Washington: International Monetary Fund).

Girton, Lance, and Don Roper, 1977, “A Monetary Model of Exchange Market Pressure Applied to the Postwar Canadian Experience," American Economic Review, Vol. 67, pp. 537-48.

Goldfajn, Ilan and Taimur Baig, 1998, "Monetary Policy in the Aftermath of Currency Crises: The Case of Asia," IMF Working Paper 99/180 (Washington: International Monetary Fund).

Goldfajn, Ilan and Poonam Gupta, 1998, "Does Tight Monetary Policy Stabilize the Exchange Rate?" IMF Working Paper 99/42 (Washington: International Monetary Fund).

Hamilton, James D., 1994, Time Series Analysis (Princeton: Princeton University Press).

International Monetary Fund, various years, International Financial Statistic (Washington: International Monetary Fund).

Kaminsky, Graciela. and Sergio Schmukler, 1998, “The Relationship Between Interest Rates and Exchange Rates in Six Asian Countries," (unpublished; Washington: World Bank).

Kaminsky, Graciela, Saul Lizondo, and Carmen M. Reinhart, 1998, "Leading Indicators of Currency Crises," IMF Staff Papers, Vol. 45, pp. 1-48.

Kashyap, Anil, Jeremy Stein, and David Wilcox, 1993, "Monetary Policy and Credit Conditions: Evidence from the Composition of External Finance," American Economic Review, Vol. 83, pp. 78-98.

Krugman, Paul, 1998, “Will Asia Bounce Back?” Speech for Credit Suisse First Boston, Hong Kong, March.

Lane, T., Atish R. Ghosh, Javier Hamann, Steven Phillips, Marianne Schulze-Ghattas, and Tsidi Tsikata, 1999, IMF-Supported Programs in Indonesia, Korea, and Thailand: A Preliminary Assessment, IMF Occasional Paper 178 (Washington: International Monetary Fund).

Radelet, Steven and Jeffery D. Sachs, 1998, "The East Asian Financial Crisis: Diagnoses, Remedies, Prospects," Brookings Papers on Economic Activity, No. 1, pp. 1-90.

Sims, Christopher, 1980, "Macroeconomics and Reality," Econometrica, Vol. 48, pp. 1-48.

Tanner, Evan, 1998, "Deviations from Uncovered Interest Parity: A World-Wide Guide to Where the Action Is," IMF Working Paper 98/117 (Washington: International Monetary Fund).

\footnotetext{
1990s," IMF Working Paper 99/114 (Washington: International Monetary Fund).
} 


\section{EXC HANGE MARKET PRESSURE AND MONETARY POUCY}

Weymark, Diana N., 1995, "Estimating Exchange Market Pressure and the Degree of Exchange Market Intervention for Canada," Journal of International Economics, Vol. 39, pp. 273-95.

—, 1998 , “A General Approach to Measuring Exchange Market Pressure," Oxford Economic Papers, Vol. 50, pp. 106-21.

Wohar, Mark E. and Bun Song Lee, 1992, “Application of the Girton-Roper Monetary Model of Exchange Market Pressure: The Japanese Experience, 1959-1986," Indian Journal of Economics, Vol. 72, pp. 379-407. 